\title{
Expression of MicroRNA-221 in Korean Patients with Multiple Myeloma
}

\author{
Woo-Soon Choi \\ Department of Clinical Laboratory Science, Songho University, Hoengseong, Korea
}

\section{한국인의 다발성골수종 환자에서 MicroRNA-221의 발현}

\author{
최우순 \\ 송호대학교 임상병리과
}

\begin{abstract}
Multiple myeloma ( $\mathrm{MM}$ ) is the leading cause of death among hematologic neoplasms. Recently, microRNA has been reported to be useful in the diagnosis of multiple myeloma. This study examined whether miR-221 could be used as a diagnostic marker for multiple myeloma. The study was performed on 20 patients with multiple myeloma without any other hematological diseases. MicroRNA extraction was performed using formalin-fixed paraffin-embedded (FFPE) tissues obtained from the bone marrow of patients with multiple myeloma. miR-15a, miR-16, miR-21, miR-181a, and miR-221 were selected as the microRNA target genes for multiple myeloma. The significance of microRNA was based on a fold change of $<1.5$. To quantify the fold changes, data normalized to the human gene, SNORD43, were used as the values of the patient group. Fold change values greater than 1.5 were defined as "overexpression", whereas values less than -1.5 were defined as "underexpression". Of note, 65.0\% (13/20) of samples showed significant "overexpression" in the levels of miR-221 expression and plasma cells with a group of more and less than 30\% in MM patients did not show any significance of plasma cell $(P<0.05)$. The results of other studies showing a correlation between the expression of miR-221 and MM in Caucasians were confirmed. These results suggest that miR-221 may be a useful indicator for diagnosing patients with MM. In conclusion, miR-221 is useful in the diagnosis and determining the prognosis of multiple myeloma in Koreans.
\end{abstract}

Key words: Bone marrow, Hematologic neoplasms, MicroRNAs, Multiple myeloma, Plasma cells

This is an Open Access article distributed under the terms of the Creative Commons Attribution Non-Commercial License (http://creativecommons.org/licenses/by-nc/4.0) which permits unrestricted non-commercial use, distribution, and reproduction in any medium, provided the original work is properly cited.

Copyright ( 2018 The Korean Society for Clinical Laboratory Science. All rights reserved.

\author{
Corresponding author: Woo-Soon Choi \\ Department of Clinical Laboratory Science, \\ Songho University, 210 Namsan-ro, \\ Hoengseong 25242, Korea \\ Tel: 82-33-340-1141 \\ Fax: 82-33-340-1127 \\ E-mail:woojung211@songho.ac.kr
}

Received: March 23, 2018 Revised $1^{\text {st. }}$ April 7, 2018 Revised 2 $2^{\text {nd }}$ : April 22, 2018 Revised 3 ${ }^{\text {rd: }}$ April 26, 2018 Accepted: April 26, 2018

\section{INTRODUCTION}

Multiple myeloma (MM) is a major hematologic neoplasms characterized by plasma cell accumulation in the bone marrow due to abnormal cell differentiation and proliferation. Bone pain, bone edema, fractures, spinal stenosis, and other symptoms are often encountered, and bone-related disorders are present in about $70 \%$ of patients diagnosed with MM. In addition, MM-related complications are impaired kidney function, thrombocytopenia, leukopenia, and others. Low platelet counts helps easily diagnose leukemia, a cancer of the blood, however, MM-the leading cause of death in hematologic neoplasms - is often undetected until late in the course of disease because patients experience no symptoms despite the bone damage [1-3]. Multiple myeloma (MM) is a tumor 
of antibody-secreting plasma cells (PCs) characterized by the clonal expansion and accumulation of monotypic PCs in the bone marrow (BM). It causes about $1 \%$ of neoplastic diseases and 13\% of hematological malignancies. Clinically, MM patients exhibit one or more symptoms including lytic bone disease, hypercalcemia, anemia, and compromised renal functions. MM is always preceded by an asymptomatic premalignant stage called monoclonal gammopathy of undetermined significance (MGUS), which progresses to myeloma or related malignancies at a rate of $1 \%$ per year [4-9].

MicroRNAs (miRNAs) have also been shown to play crucial roles in the onset of solid tumors and hematologic neoplasms by acting as either tumor suppressors or oncogenes depending on their target genes. Studies are ongoing to better understand the expression patterns of miRNA in normal and pathological conditions. In particular, there is great interest in the potential of miRNA to serve as biomarkers and numerous reports have focused on the effects of miRNA in acute myeloid leukemia, myocardial infarction, and different cancers (eg, prostate, breast, uterine, colorectal, and pancreatic) [10-16].

A number of recent studies have looked into circulating miRNAs for their potential as novel biomarkers. In one study comparing plasma miRNA profile between MM patients and healthy controls, six miRNAs (miR-148a, miR-181a, miR-20a, miR-221, miR-625, and miR-99b) were found upregulated in MM patients. Notably, miR-15a, miR-16, miR-181a, miR-20a, miR-221, and miR625 were identified previously to be unregulated in the plasma cells of MM or MGUS [17-23]. Importantly, there have been no studies examining miRNA expression in Korean patients with MM. MicroRNA target genes were selected based on previous studies [16, 17, 19]. that reported underexpression of miR-15a and miR-16 [4, 24], that note the overexpression of miR-21 [5, 16], where overexpression of miR-181a and miR-221 were reported. The microRNA selection was randomly selected to account for the frequency of multiple myeloma-associated thesis.

Here, we compared the expression of genes between
Westerners and Korean by choosing miR-15a, miR-16, miR-21, miR-181, and miR-221 which were reportedly associated with MM. Moreover, we aimed to determine if microRNAs could be used as a biomarker in patients with MM. In this study, miR-221 was reported to be overexpression in Western studies, but it was underexpression in previous studies. We tried to find out whether these results are characteristic of Korean people or other causes.

\section{MATERIALS AND METHODS}

\section{Clinical samples}

This study was conducted between January 2013 and January 2015 in the Daejeon St. Mary's Hospital, Daejeon, Korea. Experiments were performed on patients who were confirmed as multiple myeloma during the study. This study was conducted in accordance with recommendations of the local ethic committee and the Helsinki Declaration. Before the procedures written informed consent was obtained from all research participants in the study. It was found that miR-221 is contrary to the previous research. Overexpression was reported in westerners, but results of underexpression in vineyard were obtained. Also, there was not enough frequency in precedent reseach. In order to obtain more objective results, sample selection was carried out directly and the number of specimens was increased [25]. The International Myeloma Working Group diagnostic criteria were used [28]. Twenty patients with multiple myeloma (without any other disease). The mean age of 11 male subjects was 61 years, and the mean age of 9 female subjects was 63 years. The inclusion criteria of subjects were the presence of with multiple myeloma without neoplastic diseases. Laboratory testing of specimens of patient with multiple myeloma diagnosed in the Catholic University of Korea Daejeon St. Mary's Hospital.

\section{Processing of samples}

RNA lysates extracted from formalin-fixed paraffinembedded (FFPE) tissues of patients with MM was hybridized to capture extender and target probes in a 
microplate coated with capture probes at room temperature. Pre-amplifiers were hybridized (pre-amplifier stage), followed by bDNA hybridization (amplifier stage). Subsequently, specimens were interpreted using luminometer (Panomics, USA) by adding a chemiluminescent substrate solution (QuantiGene 2.0 miRNA Assay, Affymetrix, USA). Normalization was done using the human gene SNORD43 (small nucleolar RNA, C/D box 43) (Figure 1).

\section{1) RNA extraction and quantification}

Bone marrow aspirate FFPE tissues were sliced into 15 stripes at a thickness of $5 \mu \mathrm{m}$ diameter, and then collected into a $1.5 \mathrm{~mL}$ microtube. Subsequently, 606 microliter solution mixed with $600 \mu \mathrm{L}$ homogenization solution and $6 \mu \mathrm{L}$ proteinase K $(100 \mu \mathrm{g} / \mathrm{mL})$ (QuantiGene Sample Processing Kit, Affymetrix, Santa Clara, CA, USA) was added to each microtube containing specimen by making the solution into the equal number of specimens. This process was repeated until clear supernatant was obtained without paraffin or sediment. Extracted supernatants were used in the next phase.

For a patient and blank specimens, $40 \mu \mathrm{L}$ working solution and $40 \mu \mathrm{L}$ human gene $S N O R D 43$ were mixed and divided into two wells using the procedure above. The mixtures were centrifuged at $240 \mathrm{rpm}$ for $20 \mathrm{sec}$ in rack dedicated overhead stirrer, transferred to $6 \pm 1^{\circ} \mathrm{C}$ heating block, and then left to react for 16 hours. After the reaction, the next phase was carried out.

\section{2) Data analysis and software based selection of endogenous reference genes}

After removing sealing films covered on Capture Plates that were left to react in the incubator, a $200 \mu \mathrm{L}$ of prepared washing buffer was transferred to each well using multichannel pipettes. After eliminating buffer solution completely, A $100 \mu \mathrm{L}$ of 2.0 Preamplifier solution prepared in advance was transferred to each well, and then plates were left to react for an hour at $46^{\circ} \mathrm{C}$ after pressing sealing films on the plates. The three phases of washing in the above was performed to the plates, and a $100 \mu \mathrm{L}$ of prepared 2.0 Amplifier solution was added to each well. they were left to react for an hour at $46^{\circ} \mathrm{C}$. A 100 $\mu \mathrm{L}$ of prepared Label Probe was added to each well, and then the plates were left to react for an hour within $46^{\circ} \mathrm{C}$ heating block after pressing sealing films on the plates.

\section{3) Detection}

Capture Plates completed with the reaction went through three phases of washing, and then a $100 \mu \mathrm{L}$ of 2.0 substrate solution was added. The Plates were covered with sealing film and left to react for $5 \mathrm{~min}$ at room temperature. Specimens were interpreted using luminometer (Lumigen APS-5Capture, Panomics, Santa Clara, CA, USA) within 15 min and quantified as relative light units (RLUs).

\section{Statistical analysis}

For statistical analysis, the paired t-test was used to determine the significance between the experimental group (patients with $\mathrm{MM}$ and the control group and between groups with bone marrow plasma cell levels of greater than or less than $30 \%$ ( $>30 \%$ and $<30 \%$ groups). Correlation analysis was conducted using the Pearson correlation. Graphs were created using the error bar graph (SPSS PASW Statistics 18.0, SPSS inc, Chicago, IL, USA,), and $P$-values less than 0.05 were considered statistically

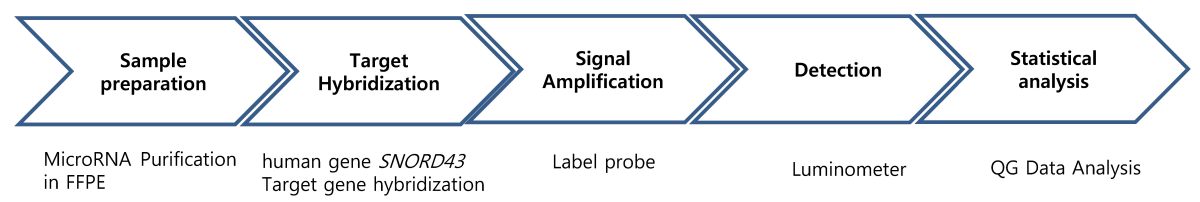

Figure 1. Specimen processing of patients with multiple myeloma. RNA lysates extracted from formalin-fixed paraffin-embedded (FFPE) tissues of patients with MM was hybridized. Normalization was done using the human gene SNORD43 and target gene hybridization. Next, amplify microRNA by attaching label probe. Specimens were interpreted using luminometer. Statistical analysis was performed using QG data analysis of Affymetrix miRNA array. 
significant. Fold change values were analyzed using QG data analysis of Affymetrix miRNA array (Thermo Fisher Scientific, Waltham, MA, USA). To quantify changes, data normalized to the human gene SNORD43 were used as the values for the patient group (patient values/control values). Fold change values greater than 1.5 was defined as "overexpression", whereas values less than -1.5 was defined as "underexpression" [26-27]. The unpaired T-test was applied to statistically evaluate the expression by single TaqMan validation assays. A linear correlation analysis was performed between expression fold changes (FC) of differentially expressed miRNA in FFPE and serum and tumor diameters. Statistical significance was established at a $P<0.05$.

\section{RESULTS}

\section{Clinical characteristics of subjects}

This study involved a total of 25 cases, 20 patients diagnosed with MM (and with no other neoplastic diseases) and 5 Westerners without neoplastic diseases (control group). The study comprised 20 patients each with more than and less than 30\% plasma cells in the bone marrow (Table 1).

\section{Analysis results of microRNAs}

As shown in Tables 2 5, when compared with the control group, mean changes in miRNA values are as follows: miR-15a (0.2), miR-16 (0.1), miR-21 (-0.6),

Table 1. Chromosomal karyotype and plasma cell of 20 patients with multiple myeloma

\begin{tabular}{ccc}
\hline Specimen & Chromosome karyotype & $\begin{array}{c}\text { Plasma } \\
\text { cell (\%) }\end{array}$ \\
\hline 1 & $46, \mathrm{XX}(20)$ & 31 \\
2 & $46, \mathrm{XX}(20)$ & 12 \\
3 & $46, \mathrm{XY}(11)$ & 31 \\
4 & $46, \mathrm{XY}(20)$ & 11 \\
5 & $46, \mathrm{XY}$, add $(1)(\mathrm{p} 36.1)(2) / 46, \mathrm{XY}(18)$ & 19 \\
6 & $46, \mathrm{XY}(20)$ & 23 \\
7 & $46, \mathrm{XY}(20)$ & 76 \\
8 & $46, \mathrm{XX}(20)$ & 18 \\
9 & $46, \mathrm{XY}(20)$ & 49 \\
10 & $46, \mathrm{XY}(6)$ & 94 \\
11 & $45, \mathrm{X},-\mathrm{X}(3) / 46, \mathrm{XX}(17)$ & 12 \\
12 & $45, \mathrm{X},-\mathrm{Y}(3) / 46, \mathrm{XY}(9)$ & 33 \\
13 & $46, \mathrm{XX}(12)$ & 32 \\
14 & $46, \mathrm{XX}(20)$ & 36 \\
15 & $46, \mathrm{XY}(20)$ & 49 \\
16 & $46, \mathrm{XX}(20)$ & 23 \\
17 & $45, \mathrm{X}, \mathrm{Y},-\mathrm{Y}(3) / 46, \mathrm{XY}(9)$ & 33 \\
18 & $46, \mathrm{XY}(11)$ & 29 \\
19 & $46, \mathrm{XY}(20)$ & 20 \\
20 & $46, \mathrm{XX}(20)$ & 13 \\
\hline
\end{tabular}

Table 2. Fold change of individual microRNAs in multiple myeloma patients

\begin{tabular}{|c|c|c|c|c|c|}
\hline Cases & $\operatorname{miR}-15 a$ & $\operatorname{miR}-16$ & $\operatorname{miR}-21$ & $\operatorname{miR}-181 a$ & $\operatorname{miR}-221$ \\
\hline 1 & 0.3 & 0.6 & 2.1 & 2.7 & 1.1 \\
\hline 2 & 0.2 & -0.2 & -0.8 & -2.3 & 2.0 \\
\hline 3 & -0.1 & 1.0 & -2.1 & -12.9 & 9.6 \\
\hline 4 & 1.3 & 1.1 & 0.6 & 2.3 & 1.9 \\
\hline 5 & 0.5 & 0.5 & 0.7 & 1.9 & 1.6 \\
\hline 6 & -2.2 & -2.5 & -1.8 & -4.2 & 5.9 \\
\hline 7 & 1.3 & -1.1 & -3.4 & -5.5 & 29.6 \\
\hline 8 & 0.3 & 0.3 & 0.6 & 1.3 & 0.7 \\
\hline 9 & 0.0 & -0.4 & -1.8 & -8.3 & 8.9 \\
\hline 10 & 0.1 & 0.1 & 0.1 & 0.4 & 0.5 \\
\hline 11 & 0.8 & 0.7 & 1.0 & 2.8 & 1.7 \\
\hline 12 & 0.2 & 0.3 & 0.3 & 0.9 & 0.2 \\
\hline 13 & 0.6 & 1.2 & 1.0 & 4.3 & -8.1 \\
\hline 14 & -0.1 & 0.1 & -0.8 & 3.0 & 5.0 \\
\hline 15 & -0.1 & 0.0 & 0.2 & 1.4 & 2.5 \\
\hline 16 & 0.1 & 0.0 & -1.8 & -1.9 & 3.6 \\
\hline 17 & 0.0 & 0.1 & -7.5 & -1.6 & 5.1 \\
\hline 18 & -0.4 & -0.4 & 0.9 & -0.9 & -31.4 \\
\hline 19 & 0.1 & 0.2 & 0.1 & 0.7 & 0.1 \\
\hline 20 & 0.1 & 0.2 & 0.0 & 1.1 & 34.5 \\
\hline
\end{tabular}

*Significance of fold change: $1.5<$ patient result, patient result $>-1.5$. 
Table 3. Results of expressed as Fold change of the microRNA in multiple myeloma

\begin{tabular}{lccc}
\hline MicroRNA & $1.5<$ patients & Patients $<-1.5$ & Expression \\
\hline miR-15a & 0 & $1(5.0 \%)$ & - \\
miR-16 & 0 & $1(5.0 \%)$ & - \\
miR-21 & $1(5.0 \%)$ & $6(30.0 \%)$ & Downexpression \\
miR-181a & $6(30.0 \%)$ & $7(35.0 \%)$ & - \\
miR-221 & $13(65.0 \%)$ & $2(10.0 \%)$ & Underexpression \\
\hline
\end{tabular}

Table 4. MicroRNAs differentially expressed between MM and controls

\begin{tabular}{lccc}
\hline MicroRNA & $\begin{array}{c}\text { Average } \\
\text { Fold change }\end{array}$ & $\begin{array}{c}\text { Pearson } \\
\text { correlation }\end{array}$ & $\begin{array}{c}\text { Chromosomal } \\
\text { location }\end{array}$ \\
\hline miR-15a & 0.2 & 0.995 & $13 \mathrm{q} 14.2$ \\
$\operatorname{miR}-16$ & 0.1 & 0.999 & $13 \mathrm{q} 14.2$ \\
$\operatorname{miR}-21$ & -0.6 & 0.994 & $17 \mathrm{q} 23.1$ \\
$\operatorname{miR}-181 \mathrm{a}$ & -0.7 & 0.990 & $1 \mathrm{q} 32.1$ \\
miR-221 & $3.8^{*}$ & 0.994 & xp11.3 \\
\hline
\end{tabular}

*Significance of fold change: $1.5<$ patient result, patient result $>-1.5$.

miR-181a (-0.7), and miR-221 (3.8; $P<0.05)$. The total numbers of individual samples with expression patterns are significantly different than controls, 1 case (5\%) for miR-15a and miR-16 (both overexpressed), 7 cases (35\%) for miR-21 (underexpression ( $\mathrm{N}=6)$; overexpression $(\mathrm{N}=1)$, 15 cases $(75 \%)$ for miR-181 (overexpression $(\mathrm{N}=6)$; underexpression ( $\mathrm{N}=10)$, and 15 cases (75\%) for miR-221 (underexpression $(\mathrm{N}=2)$; overexpression $(\mathrm{N}=13)$. To sum up, the overexpression of miR-221 was observed in 13 cases (65\%), while $6(30 \%)$ and $7(35 \%)$ of cases displayed overexpression and underexpression of miR-181 a compared with controls, respectively (Figure 2, Table 3, 4). Correlation coefficients of two repeated test results were 0.995 in miR-15a, 0.999 in miR-16, 0.994 in miR-21, 0.990 in miR-181a, and 0.994 in miR-221, showing a high correlation between the results (Table 4).

\section{Plasma cell concentrations of bone marrow and miRNA expression levels}

To assess the potential role of plasma cells concentration within bone marrow and miRNA expression levels, the 20 patients within the experimental group were divided into one of 2 groups (ie, those with plasma cell concentrations within bone marrow of $<30 \%$ and $>30 \%$ ).
Table 5. Average fold change between plasma cell more then 30\% and less then $30 \%$ in multiple myeloma patients

\begin{tabular}{lccc}
\hline MicroRNA & $\begin{array}{c}30 \%< \\
\text { plasma cell }\end{array}$ & $\begin{array}{c}\text { Plasma cell } \\
<30 \%\end{array}$ & $P$-value \\
\hline miR-15a & 0.2 & 0.1 & 0.657 \\
miR-16 & 0.2 & 0.0 & 0.538 \\
miR-21 & -1.2 & -0.1 & 0.261 \\
miR-181a & -1.6 & 0.1 & 0.438 \\
miR-221 & 5.4 & 2.1 & 0.575 \\
\hline
\end{tabular}

$\star P<0.05$ : Significance, $P$-values were calculated by regression analysis.

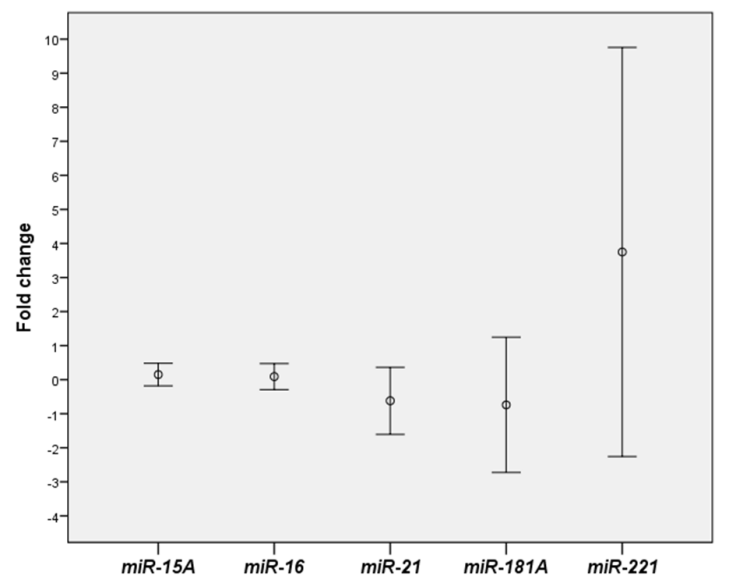

Figure 2. Validation of microRNA expression level in multiple myeloma. The amount of miR-15A, miR-16, miR-21, miR-181A and miR-221 in formalin-fixed paraffin-embedded (FFPE) tissues obtained from the bone marrow. Results were expressed as fold change of the microRNA on house keeping gene SNORD43.

Next, mean miRNA expression levels of these groups were compared with the control group. In summary, and as shown in Table 5, no significant differences were observed for the expression of any miRNA tested between the $<30 \%$ and $>30 \%$ plasma cell groups. Consequently, our findings suggest that there is no significant impact of plasma cell concentration within bone marrow on the expression levels of miRNA in patients with MM.

\section{DISCUSSION}

The miRNA is an endogenous non-protein coding small RNA molecule that negatively regulates gene expression by the degradation of messenger RNA (mRNA) or the suppression of mRNA translation. miRNA plays important roles in physiologic processes such as cellular development, differentiation, proliferation, apoptosis, and stem 
cell self-renewal. Studies show that deregulation of miRNA expression is closely associated with tumorigenicity, invasion, and metastasis. The functionality of aberrant miRNAs in cancer could act either as oncogenes or tumor suppressors during tumor initiation and progression. Similar to protein-coding gene regulation, dysregulation of miRNAs may be related to changes in miRNA gene copy numbers, epigenetic modulation, polymorphisms, or biogenesis modifications. Elucidation of the miRNA expression profiles (miRNomes) of many types of cancers is starting to decode the regulatory network of miRNA-mRNA interactions from a systems biology perspective [29]. Upregulation of miR-221/222 has been found in several solid and hematologic malignancies, including multiple myeloma (MM), and is thought to have oncogenic potential and promote cell proliferation via down-regulation of p27 and/or p57, negative regulators of cell cycle progression. We previously demonstrated that upregulation of both miRNAs occurs in malignant plasma cells (PCs) from multiple myeloma (MM) patients belonging to TC2 and TC4 (traslocation/Cyclin) groups. A rising body of evidence suggests that silencing miRNAs with oncogenic potential could represent a novel approach for human cancer therapy. We previously demonstrated that silencing miR-221/222 exerts significant anti-MM activity and triggers canonical targets in vitro and in vivo [30]. The aim of this study was to investigate the relationship between microRNA and miRNA-221 in patients with multiple myeloma.

In this study, underexpression (of at least 1.5-fold compared with controls) of miR-15a and miR-16 levels were observed in $5.0 \%$ and $35 \%$ of samples from patients with MM, respectively. Although these differences are not significantly different, in part perhaps because of the small sample size, our findings are consistent with those of who observed underexpression of miR-15a and miR-16 in patients with MM [16, 17]. Underexpression $(<1.5$ fold change compared with controls) of miR-21 was seen in 6 cases $(30.0 \%)$, a finding that contradicts those by who reported that miR-21 overexpression is associated with an increased incidence of various cancers (eg, colorectal, breast, liver, pancreatic, lung, and gastric) and lymphomas [5, 17, 26]. Overexpression of miR-181a in patients with MM has been implicated in the development of breast, pancreatic, and prostate cancer [5, 16]. In this study, the overexpression of miR-181a was seen in 6 cases $(30.0 \%)$, while underexpression was observed in 7 cases (35.0\%), again differing from the results of previous studies. The reported overexpression of miR-221 in patients with MM, results that match well with the observations in this study (overexpression in 13 (65.0\%) cases). In conclusion, this study demonstrates that in miR-221 expression levels may be an important marker in Korean patients with MM; these findings are similar to previous studies on Westerners. In contrast, contradicting results were found for miR-21. No significance was shown in miR-15, miR-16, and miR-181a (Figure 1, Table 3, 4). Conflicting results may be due to the exclusion of patients with the abnormality in chromosome related with MM. Through karyotype analysis, patients with deletion of 14q32, 13q, and 17p associated with MM, abnormal chromosome 1 (loss on $1 \mathrm{p}$ and gain of $1 \mathrm{q}$ ), and partial trisomy 1q were excluded since chromosome abnormality could impact microRNA expression levels and our sample size was not large enough to characterize the potential effects of these abnormalities.

Minor and major criteria for the diagnosis of multiple myeloma according to the definition of the $\mathrm{WHO}$ classification include different categories of the bone marrow plasma cell count: a shift from the 10 30\% group to the $>30 \%$ group equals a shift from a minor to a major criterium [31]. When comparing the expression profiles of miRNA in patients with plasma cell concentrations within the bone marrow of $>30 \%$ and $<30 \%$, no significances were observed for the miRNA tested (miR-15a, miR-16, miR-21, miR-181a, and miR-221; $P>0.05$ ). Therefore, plasma cells are not expected to have a significant impact on the expression levels of miRNA in patients with MM (Table 5).

In a study of Westerners, miR-221 was overexpressed [16, 17, 19]. However, underexpression was found in previous studies [25]. This is to confirm the characteristic 
result of Korean people. In addition, we tried to confirm whether there was a problem in selection of samples because frequency was low. The specimens were selected for more specific multiple myeloma patients and 20 cases were performed. As a result, miR-16 showed the same result, and miR-221 obtained the result of overexpression. This is thought to be the result of careful examination of multiple myeloma patients. In the present study, we found that miR-221 could be used in the diagnosis of multiple myeloma patients together with miR-16. In a Western population study, miR-221 reported that it could be used as a potential prognostic and diagnostic marker for multiple myeloma [32].

In conclusion, we confirm the results of other studies showing a correlation between the expression of miR-221 and MM in Westerners, but generated conflicting results for the expression levels of miR-21 in Korean patients with MM compared with Westerners. No significant differences in the expression profiles of miR-15, miR-16, and miR-181a were observed. These results suggest that miR-221 may be a useful indicator for diagnosing patients with MM.

\section{요 약}

다발성 골수종(MM)은 혈액 종양의 주요 사망 원인이다. 최 근에 다발성 골수종 진단에 microRNA를 이용한 실험이 보고 되고 있다. 이에 우리는 다발성 골수종 진단 마커로 miR-221을 이용 할 수 있는지 확인하고자 하였다. 본 연구는 다른 혈액학적 질환이 없는 다발성 골수종 환자 20 명을 대상으로 하였다. MicroRNA 추출은 다발성 골수종 환자의 파라핀 포매 조직을 이용하였다. 우리는 다발성 골수종의 microRNA 표적 유전자 로 miR-15a, miR-16, miR-21, miR-181a 그리고 miR-221 을 선택하였다. 유의성 검정은 fold change 값을 기준으로 1.5 이상 또는 -1.5 미만의 결과를 유의성이 있는 경우로 하였다. Fold change 값은 인간 유전자 SNORD43에 의해 표준화된 데 이터를 기준으로 하였다. Fold change 값이 1.5 이상은 "overexpression", -1.5 미만의 값은 "underexpression"으로 정의되었다. miR-221의 65.0\% (13/20)에서 "overexpression" 으로 유의성이 있음을 확인하였고, 다발성 골수종 환자에서 형 질세포가 $30 \%$ 이상인 그룹과 이하의 그룹은 유의성을 보이지
않았다. MiR-221은 서구인과 같은 결과를 얻었으며, 다발성 골 수종 환자에서 miR-221이 다발성 골수종 환자 진단에 매우 중 요한 지표가 될 수 있을 것으로 생각된다. 결론적으로 miR-221 은 한국인의 다발성 골수종 진단 또는 예후 지표로 활용할 수 있 음을 확인하였다.

Acknowledgements: We would like to thank Gwang-yeol Lee and Han-su Jang.

Conflict of interest: None

\section{REFERENCES}

1. Alexander DD, Mink PJ, Adami HO, Cole P, Mandel JS, Oken $\mathrm{MM}$, et al. Multiple myeloma: a review of the epidemiologic literature. Int J Cancer. 2007;120(Suppl 12):40-61. doi:10. 1002/ijc.22718.

2. Ribatti D, Nico B, Vacca A. Importance of the bone marrow microenvironment in inducing the angiogenic response in multiple myeloma. Oncogene. 2006;25:4257-4266. doi:10.1038/ Sj.onc.1209456.

3. Greipp PR, San Miguel J, Durie BG, Crowley JJ, Barlogie B, Bladé $\mathrm{J}$, et al. International staging system for multiple myeloma. J Clin Oncol. 2005;23:3412-3420. doi:10.1200/ JCO.2005.04.242.

4. Chng WJ1, Lau LG, Yusof N, Mow BM. Targeted therapy in multiple myeloma. Cancer Control. 2005;12:91-104. doi:https:// doi.org/10.1016/ S0037-1963(01)90021-6.

5. Raab MS, Podar K, Breitkreutz I, Richardson PG, Anderson KC. Multiple myeloma. Lancet. 2009;374:324-339. doi: 10.1016/ S0140-6736(09)60221-X.

6. Kumar S. Multiple myeloma-current issues and controversies. Cancer Treat Rev. 2010;36(Suppl 2):3-11. doi:10.1016/S03057372(10)70006-2.

7. Kyle RA, Therneau TM, Rajkumar SV, Offord JR, Larson DR, Plevak MF. et al. A long-term study of prognosis in monoclonal gammopathy of undetermined significance. N Engl J Med. 2002;346:564-569. doi:10.1146/annurev.arplant.57.032905. 105218.

8. Kyle RA, Therneau TM, Rajkumar SV. Prevalence of monoclonalgammopathy of undetermined significance. $\mathrm{N}$ Engl J Med. 2006;354:1362-1369. doi: 10.1056/NEJMoa054494.

9. Baffa R, Fassan M, Volinia S, O'Hara B, Liu CG, Palazzo JP, et al. MicroRNA expression profiling of human metastatic cancers identifies cancer gene targets. J Pathol. 2009;219:214-221. doi:10.1002/path.2586.

10. Kota J, Chivukula RR, O'Donnell KA, Wentzel EA, Montgomery CL, Hwang HW, et al. Therapeutic microRNA delivery suppresses tumorigenesis in a murine liver cancer model. Cell. 2009;137:1005-1017. doi:10.1016/j.cell.2009.04.021.

11. Schetter AJ, Leung SY, Sohn JJ, Zanetti KA, Bowman ED, Yanaihara N, et al. MicroRNA expression profiles associated with prognosis and therapeutic outcome in colon 
adenocarcinoma. JAMA. 2008;299:425-436. doi:10.1001/jama. 299.4.425.

12. Garzon R, Volinia S, Liu CG, Fernandez-Cymering C, Palumbo T, Pichiorri F, et al. MicroRNA signatures associated with cytogenetics and prognosis in acute myeloid leukemia. Blood. 2008;111:3183-3189. doi:10.1182/blood-2007-07-098749.

13. Porkka KP, Pfeiffer MJ, Waltering KK, Vessella RL, Tammela TL, Visakorpi T. MicroRNA expression profiling in prostate cancer. Cancer Res. 2007;67:6130-6135. doi:10.1158/0008-5472. CAN-07-0533.

14. Iorio MV, Visone R, Di Leva G, Donati V, Petrocca F, Casalini P, et al. MicroRNA signatures in human ovarian cancer. Cancer Res. 2007;67:8699-8707. doi:10.1158/0008-5472.CAN-07-1936.

15. Mattie MD, Benz CC, Bowers J, Sensinger K, Wong L, Scott GK, et al. Optimized high-throughput microRNA expression profiling provides novel biomarker assessment of clinical prostate and breast cancer biopsies. Mol Cancer. 2006;5:24. doi: 10.1186/1476-4598-5-24.

16. Roccaro AM, Sacco A, Thompson B, Leleu X, Azab AK, Azab F, et al. MicroRNAs 15 a and 16 regulate tumor proliferation in multiple myeloma. Blood. 2009;113:6669-6680. doi:10.1182/ blood-2009-01-198408.

17. Croce CM. Causes and consequences of microRNA dysregulation in cancer. Nat Rev Genet. 2009;10:704-714. doi: $10.1038 / \mathrm{nrg} 2634$.

18. Vasilatou D, Papageorgiou S, Pappa V, Papageorgiou E, Dervenoulas J. The role of microRNAs in normal and malignant hematopoiesis. Eur J Haematol. 2009;84:1-16. doi:10.1111/ j.1600-0609.2009.01348.x.

19. Corthals SL, Jongen-Lavrencic M, de Knegt Y, Peeters JK, Beverloo HB, Lokhorst HM, et al. Micro-RNA-15a and micro-RNA-16 expression and chromosome 13 deletions in multiple myeloma. Leuk Res. 2010;34:677-681. doi:10.1016/ j.leukres.2009.10.026.

20. Kim YK, Yu J, Han TS, Park SY, Namkoong B, Kim DH, et al. Functional links between clustered microRNAs: suppression of cell cycle inhibitors by microRNA clusters in gastric cancer. Nucleic Acids Res. 2009;37:1672-1681. doi:10.1093/nar/ gkp002.

21. Chang HJ, Kim NK, Jeon YJ, Kim JW. The relationship between the progression of colorectal cancer and microRNA polymorphisms. Korean J Clin Oncol. 2011;7:50-57. doi: 10.14216/kjco.11019.

22. Son JW, Kim YJ, Cho HM, Lee SY, Jang JS, Choi JE, et al.
MicroRNA expression profiles Korean non-small cell lung cancer. Tuberc Respir Dis. 2009;67:413-421. doi:https://doi. org/10.4046/trd.2009.67.5.413.

23. Lee HJ, Park CS, Deftereos G, Morihara J, Stern JE, Hawes SE, et al. MicroRNA expression in ovarian carcinoma and its correlation with clinicopathological features. World J Surg Oncol. 2012;10:174. doi:10.1186/1477-7819-10-174.

24. Löffler D, Brocke-Heidrich K, Pfeifer G, Stocsits C, Hackermüller J, Kretzschmar AK, et al. Interleukin-6 dependent survival of multiple myeloma cells involves the Stat3-mediatde induction of microRNA-21 through a highly conserved enhancer. Blood. 2007;110:1330-1333. doi:10. 1182/blood-2007-03-081133.

25. Choi WS, Kwon KC. Expression of microRNA in paraffin embedded tissue of multiple myeloma. Korean J Clin Lab Sci. 2015;47:292-297. doi:https://doi.org/10.15324/kjcls.2015.47. 4.292.

26. Farazi TA, Spitzer JI, Morozov P, Tuschi T. miRNAs in human cancer. J Pathol. 2011;223:102-115. doi:10.1002/path.2806.

27. Tan KS, Armugam A, Sepramaniam S, Lim KY, Setyowati KD, Wang CW, et al. Expression profile of microRNAs in young stroke patients. PLoS One. 2009;4:e7689. doi:10.1371/ journal.pone.0007689.

28. Rajkumar SV, Dimopoulos MA, Palumbo A, Blade J, Merlini G, Mateos MV, et al. International myeloma working group updated criteria for the diagnosis of multiple myeloma. Lancet Oncol. 2014;15:538-548. doi:10.1016/S1470-2045(14)70442-5.

29. Wu W. MicroRNA: potential targets for the tevelopment of novel drugs?. Drugs R D. 2010;10:1-8. doi:10.2165/11537800000000000-00000.

30. Di Martino MT, Gullà A, Gallo Cantafio ME, Altomare E, Amodio $\mathrm{N}$, Leone $\mathrm{E}$, et al. In vitro and in vivo activity of a novel locked nucleic acid (LNA)-inhibitor-miR-221 against multiple myeloma cells. PLoS One. 2014;9:e89659. doi:10.1371/journal. pone.0089659.

31. Went P, Mayer S, Oberholzer, Dirnhofer S. Plasma cell quantification in bone marrow by computer-assisted image analysis. Histol Histopathol. 2006;21:951-956. doi: 10.14670/HH21.951.

32. Xiang T, Hu AX, Sun P, Liu G, Liu G, Xiao Y. Identification of four potential predicting miRNA biomarkers for multiple myeloma from published datasets. Peer J. 2017;31:e2831. doi: 10.7717/peerj.2831. 